\title{
Home-Mortgage Lending Trends in New England in 2010
}

\section{Ana Patricia Muñoz}

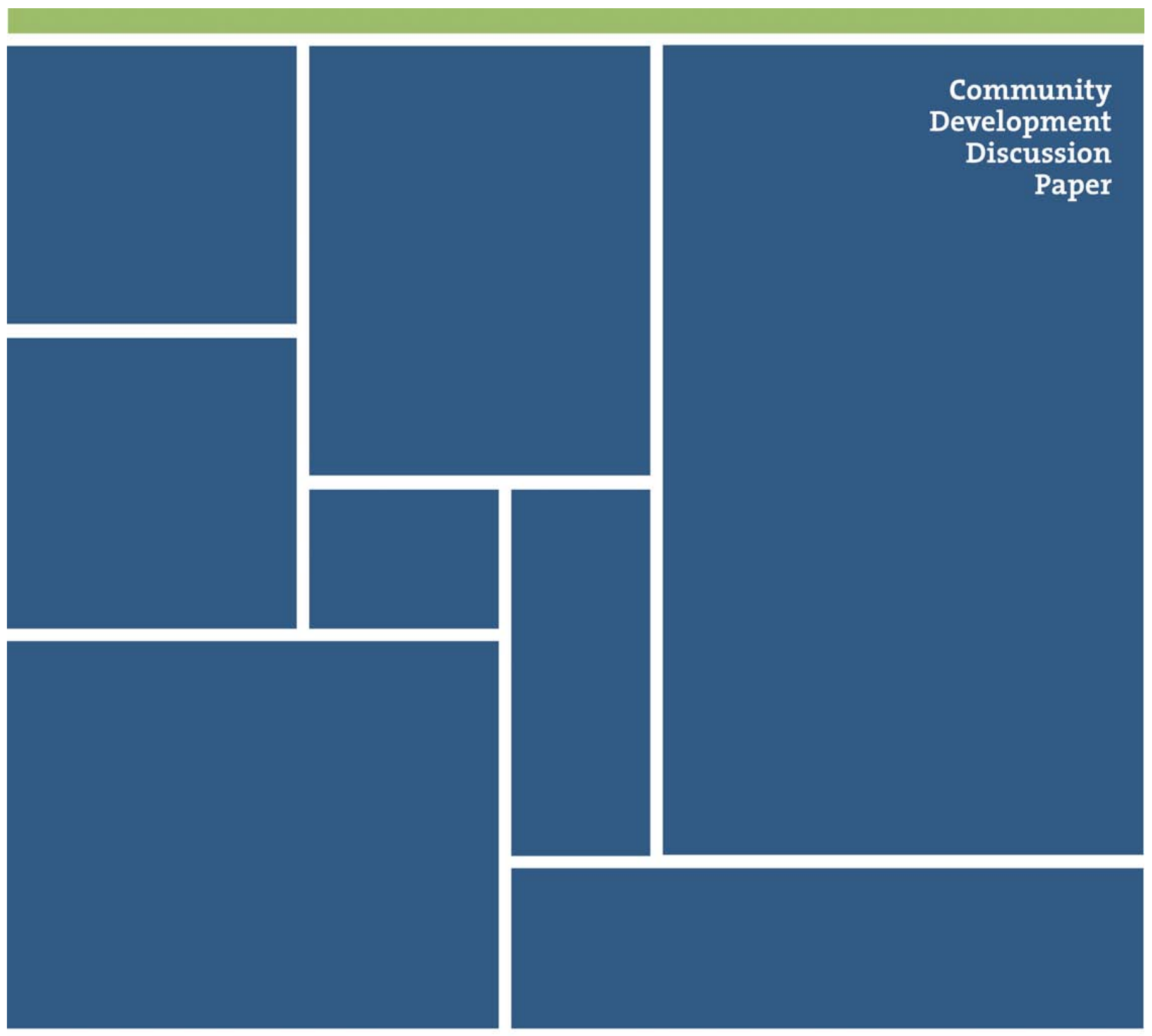




\section{Home-Mortgage Lending Trends in New England in 2010}

This brief analysis of home-mortgage lending trends in New England is based on data collected under the Home Mortgage Disclosure Act (HMDA). ${ }^{1}$ The HMDA provides information on mortgage lending trends and includes data by loan purpose, type of loan, income, and the race and ethnicity of borrowers. This report focuses on home-purchase and refinance loans in New England. ${ }^{2}$ It is important to analyze mortgages by loan purpose since changes in total mortgage loans were mainly driven by refinance loans, which accounted for three-quarters of total mortgages in the region. ${ }^{3}$

Mortgage originations in New England mirrored mortgage application trends in 2010. (See Figure 1.) Home-purchase and refinance loans declined 9 percent and 11 percent, respectively, from the previous year. The nation as a whole experienced larger drops both in home-purchase (11 percent decline) and refinance loans (17 percent decline). Home-purchase decreases in 2010 were in part caused by the expiration of the homebuyer tax credit in April $2010 .^{4}$

New England home-purchase originations have been in decline for the past four years, dropping 44 percent, from 177,000 in 2006 to 99,700 in 2010. The United States as a whole experienced even steeper declines, with home-purchase loans in 2010 (2,200,000 mortgages) totaling only half the number of loans issued in 2006.

\footnotetext{
${ }^{1}$ Data are available at the website of the Federal Financial Institutions Examination Council (FFIEC), http://www.ffiec.gov/hmda/. Detailed data for New England states may be found at www.bos.frb.org/commdev/regulatory-resources/hmda. HMDA coverage is limited to lending institutions that have at least one office in a metropolitan statistical area (MSA) - that is, a core area containing a large population nucleus. MSAs are composed of entire counties or county equivalents. Every MSA has at least one urbanized area with a population of 50,000 or more. (More information is available at www.ffiec.gov/hmda/glossary.htm)

${ }^{2}$ We exclude home-improvement loans, which represented 3 percent of mortgage loans in 2010 in New England. Data in this analysis include only first-lien Ioans for owner-occupied homes. The data exclude junior-lien Ioans, all loans for multifamily properties, and all loans for non-owner-occupied homes. We follow the classifications used by Jim Campen in the MCBC Changing Patterns series available at http://mcbc.info/reports/mortgage.

${ }^{3}$ Detailed data for New England states may be found at www.bos.frb.org/commdev/regulatory-resources/hmda 4 The American Recovery and Reinvestment Act of 2009 established a first-time homebuyer credit of $\$ 8,000$ for purchases made in 2009 before December 1. In November 2009 the tax credit was expanded and extended to eligible taxpayers who bought, or entered into a binding contract to buy, a principal residence before April 30, 2010.
} 
Despite their drop in 2010 from the previous year, New England refinance loan originations, at 299,900, were 32 percent higher in 2010 than they were in 2006. Nationwide, refinance loans increased only 1 percent, to 4,500,000 loans, in that period.

Figure 1

New England Home-Purchase and Refinance Applications and Originations, 2006-2010



Home-purchase originations in Connecticut, Massachusetts, and Vermont experienced changes similar to the region as a whole, while Rhode Island and Maine saw steeper declines in 2010 (16 percent and 11 percent drop, respectively, from the previous year). (See Figure 2.) Homepurchase loans fell close to 50 percent in Connecticut, Rhode Island, and New Hampshire from 2006 to 2010. (See Table 1.)

Figure 2

New England Home-Purchase Loan Originations by State, 2006-2010
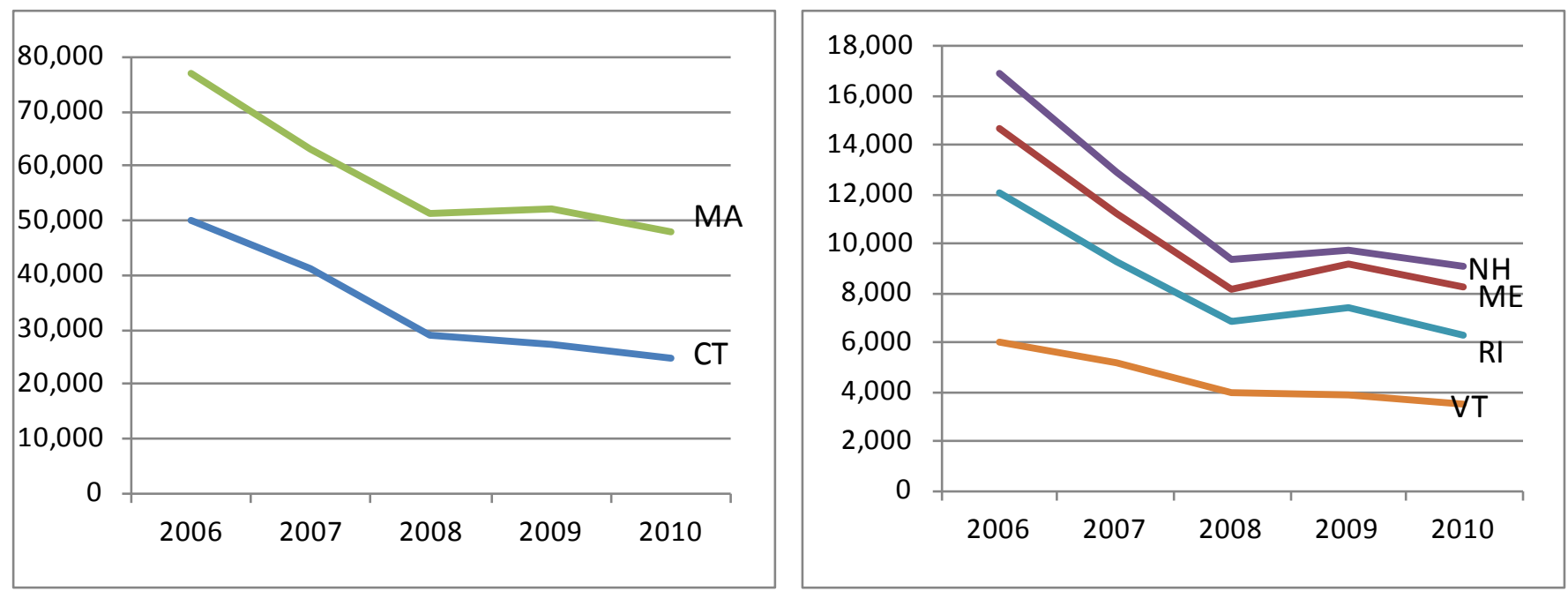
Table 1

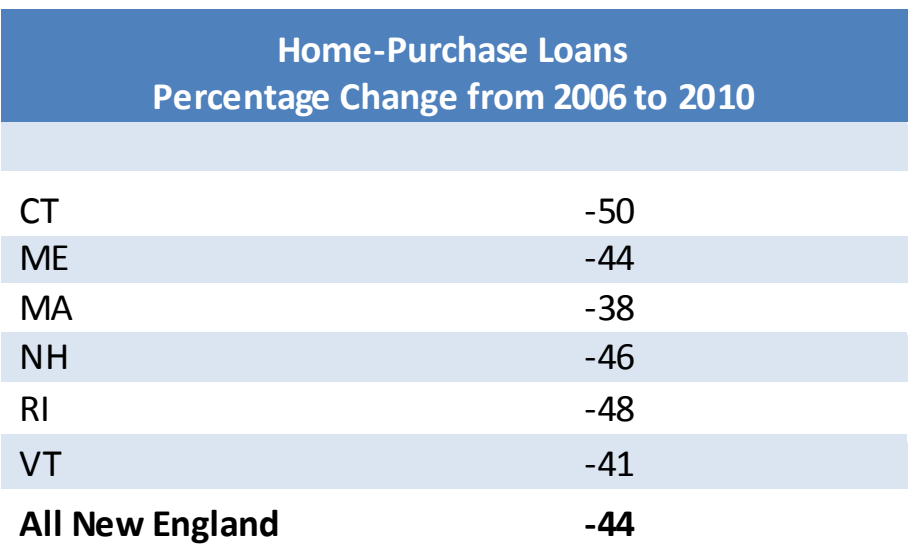

Declines in refinance loans from 2009 to 2010 varied significantly across the New England states, ranging from a 7 percent drop in Massachusetts to a 31 percent decline in Vermont. (See Figure 3.) House price drops, high unemployment rates, and tighter underwriting conditions may have been responsible for the weakened refinance activity in 2010.

With the exception of Rhode Island, however, all the New England states showed a larger number of refinance originations in 2010 than in 2006. (See Table 2.) Massachusetts had a relatively strong showing, with a 53 percent increase in refinance loans in those four years. Sharp declines in housing prices can in part explain Rhode Island's lower refinancing levels. Housing prices in that state plummeted 23 percent from peak to bottom, the largest decline in New England. (See Table 2.) The more house prices fall, the larger the percentage of borrowers with negative home equity. ${ }^{5}$ Lower home equity limits refinancing options as borrowers would need to reduce a significant portion of their loan balances to access refinance loans . As Avery et al. (2010) note, the number of refinanced loans are generally lower for borrowers in states that experienced the sharpest price declines within each credit-score group. ${ }^{6}$

\footnotetext{
${ }^{5}$ A borrower has a negative home equity when the money owed on the mortgage exceeds the current value of the home.

${ }^{6}$ See Robert B. Avery, Neil Bhutta, Kenneth P. Brevoort, and Glenn B. Canner, "The Mortgage Market in 2010: Highlights from the Data Reported under the Home Mortgage Disclosure Act," Federal Reserve Bulletin 97, no. 6 (December 2011), 28. Available at http://www.fed eralreserve.gov/pubs/bulletin/2011/pdf/2010_HMDA_final.pdf.
} 
Table 2

\begin{tabular}{|c|c|c|}
\hline \multicolumn{2}{|c|}{$\begin{array}{l}\text { Percentage Change in Refinance Loans } \\
\text { from } 2006 \text { to } 2010\end{array}$} & $\begin{array}{l}\text { FHFA House Price Change from } \\
\text { Peak to Bottom }\end{array}$ \\
\hline CT & 24 & -14 \\
\hline $\mathrm{ME}$ & 1 & -15 \\
\hline MA & 53 & -11 \\
\hline $\mathrm{NH}$ & 21 & -17 \\
\hline RI & -11 & -23 \\
\hline VT & 40 & -5 \\
\hline All New England & 32 & -17 \\
\hline
\end{tabular}

Figure 3

New England Refinance Loan Originations in New England States, 2006-2010
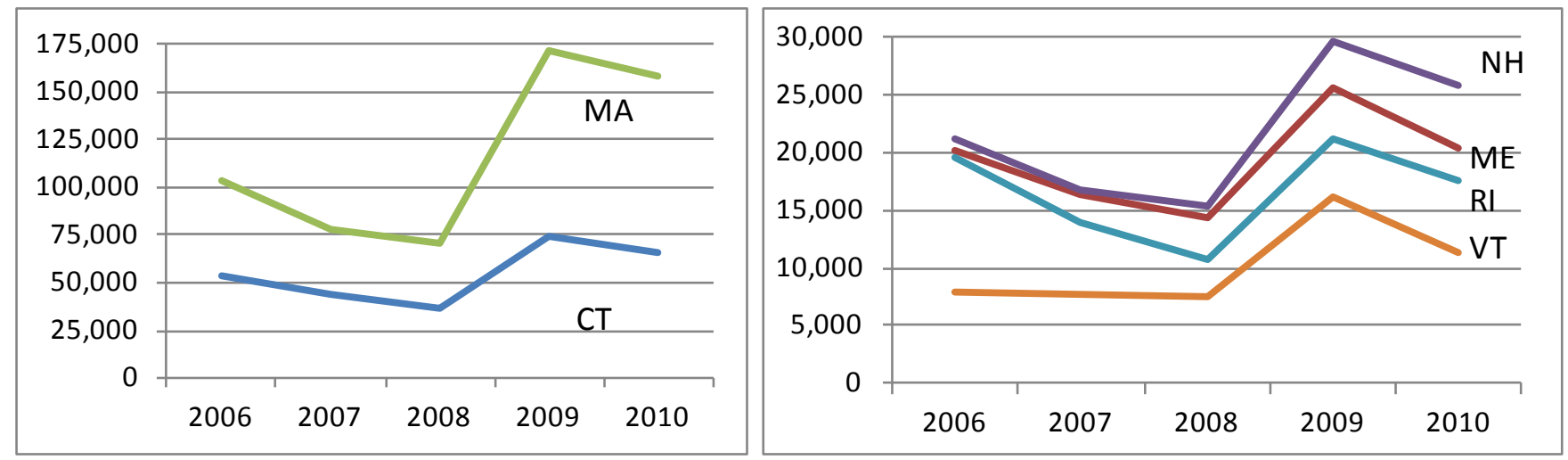

Home-purchase mortgages went down for borrowers of all races and ethnicities from 2006 to 2010. However, home-purchase loans plummeted at a much higher rate (64 percent) among blacks and Latinos than among white (40 percent) and Asian (20 percent) borrowers. (See Figure 4.) 
Figure 4

Home-Purchase Loan Originations in New England by Race/Ethnicity, 2006-2010

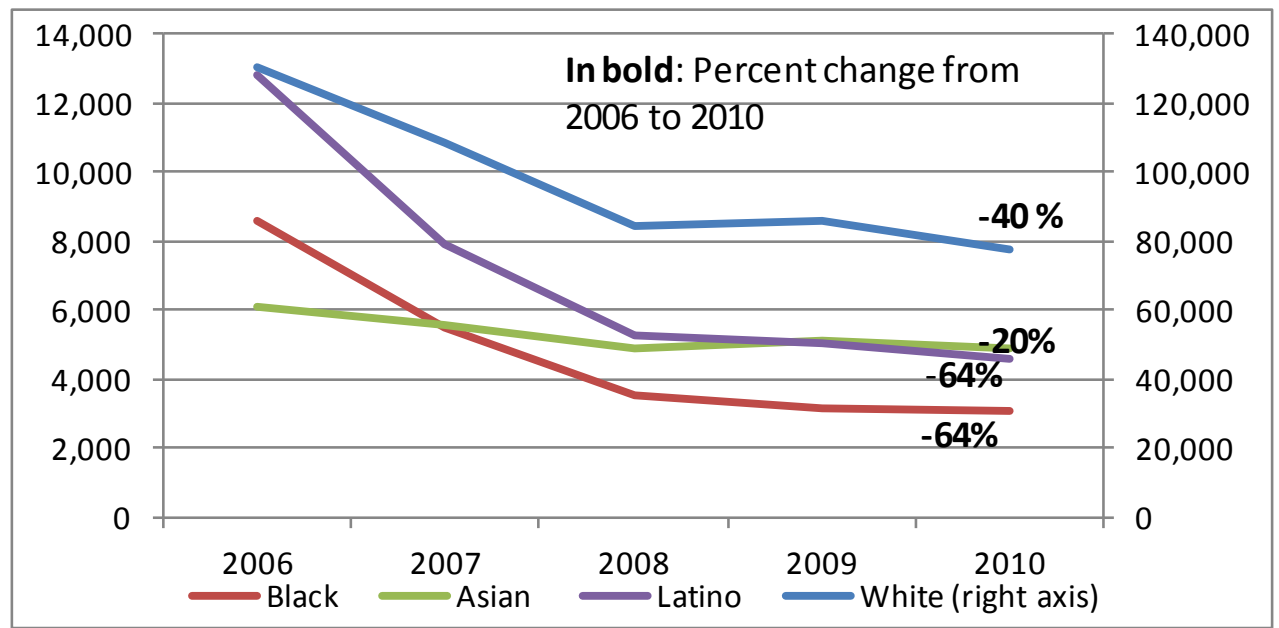

While refinance originations almost tripled among Asians and increased 48 percent among whites from 2006 to 2010, refinance loans to black and Latino borrowers declined sharply, by 67 percent and 59 percent, respectively. (See Figure 5.) $)^{7}$

Figure 5

Refinance Loan Originations in New England by Race/Ethnicity, 2006-2010

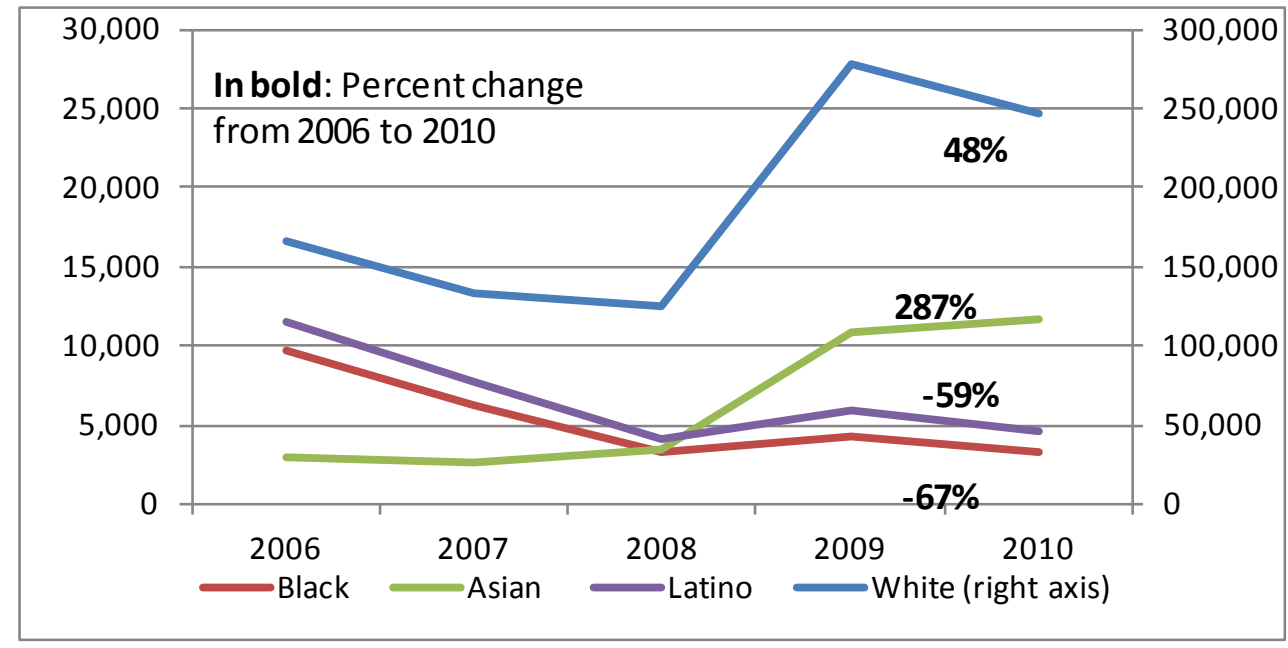

\footnotetext{
${ }^{7}$ White, black, and Asian data refer to non-Latino whites, non-Latino blacks, and non-Latino Asians. We do not present data on loans for which this information was not provided or data for "American Indian or Alaska Native" or "Native Hawaiian or Other Pacific Islander."
} 
Interestingly, low- and moderate-income (LMI) borrowers ${ }^{8}$ experienced a less dramatic fall in home-purchase originations (18 percent) than non-LMI borrowers (50 percent) from 2006 to 2010. (See Figure 6.) As a result, the share of home-purchase loans to LMI borrowers in New England increased ten percentage points, from 27 percent in 2006 to 37 percent in 2010. In refinance mortgages, by contrast, LMI borrowers only saw a 15 percent increase in originations, while non-LMI borrowers saw a 132 percent increase. Avery, Brevoort, and Canner find similar trends for the nation, noting that "the share of refinance loans to borrowers with low- or moderate incomes (LMIs) fell significantly from 2006 to 2010, while the share of homepurchase loans to such borrowers increased significantly." ${ }^{9}$ They add that although most of this growth took place in 2008 and 2009, it was sustained in 2010 when the first-time homebuyer tax credit prog ram was still in place.

Figure 6

New England Home-Purchase and Refinance Originations by Borrower Income, 2006 and 2010

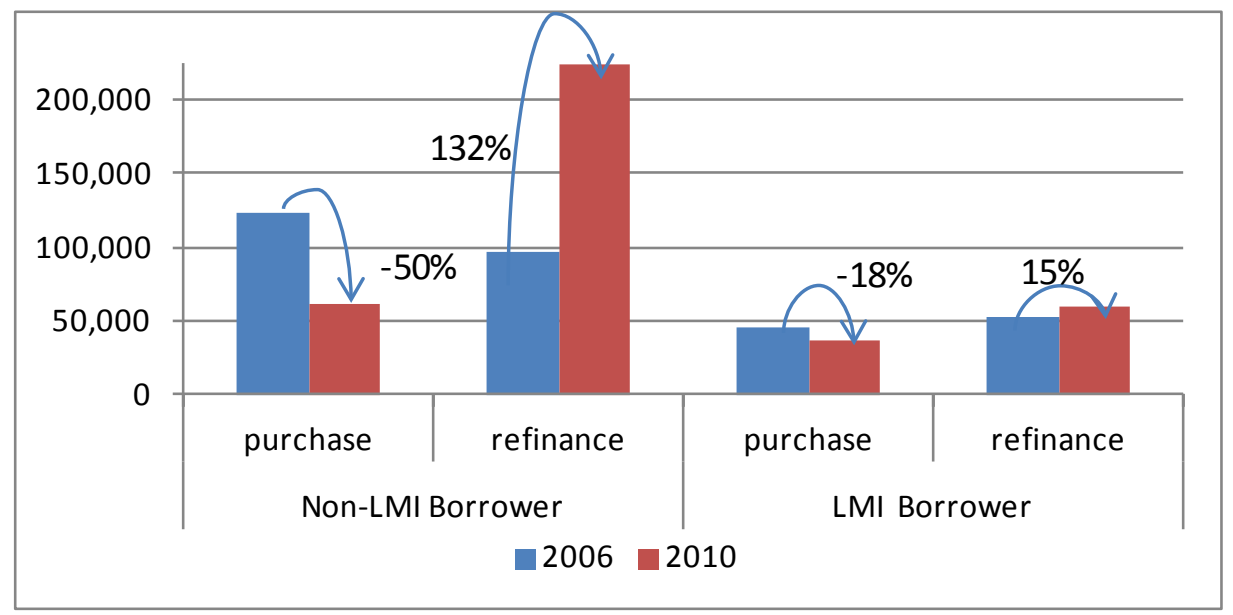

\footnotetext{
${ }^{8}$ LMI borrowers are individuals with household income, as reported in the loan application, bel ow 80 percent of the MSA median income. About 1 percent of home-purchase originations and 5 percent of refinance mortgage originations did not have income information in 2010. This might be either because the loan was not in a MSA area or because income was not reported in the und erwriting decision. Some streamlined refinance programs do not require current income to be considered in underwriting.

${ }^{9}$ Avery et al., "The Mortgage Market in 2010: Highlights from the Data Reported und er the Home Mortgage Disclosure Act," 33.
} 
When comparing LMI and non-LMI census tracts, ${ }^{10}$ it is apparent that low-income areas suffered more during the economic crisis. Home-purchase mortgages went down 58 percent in LMI census tracts from 2006 to 2010, compared with a 40 percent decline in non-LMI tracts.

Moreover, while non-LMI areas saw a sharp increase in refinance loans from 2006 to 2010, refinance originations in LMI tracts were cut in half in the same period of time. (See Figure 7.)

Figure 7

New England Refinance Originations by Census Tract Income, 2006 and 2010

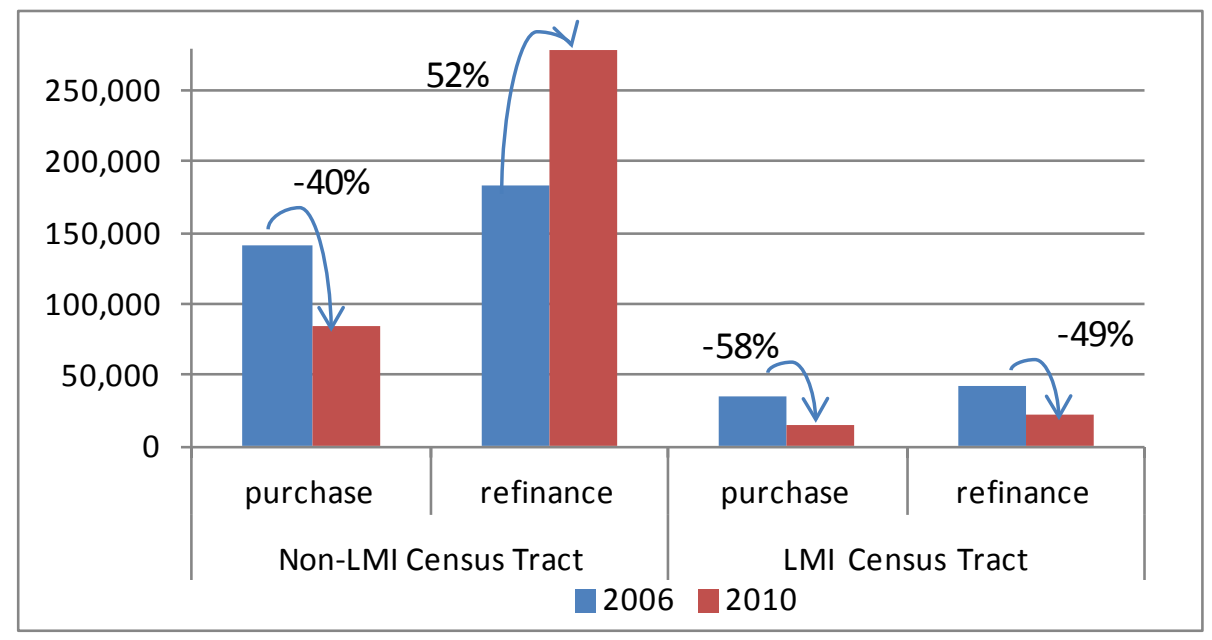

It is hard to know exactly why the share of home-purchase loans to LMI borrowers (as opposed to non-LMI borrowers) increased 10 percentage points in the $2006-2010$ period while at the same time the share of home-purchase mortgages in LMI census tracts declined. Avery, Brevoort, and Canner point out that in Neighborhood Stabilization Program (NSP) ${ }^{11}$ census tracts "much of the decline in lending in the highly distressed tracts reflects reduced inflows from higher-income borrowers. The lower income levels of new borrowers in the high-NSP tracts may inhibit the stabilization of these communities."

\footnotetext{
${ }^{10} \mathrm{LMI}$ census tracts are census tracts with median family income below 80 percent of the MSA median family income. Census tractincome is based on the 2000 census.

${ }^{11}$ High-NSP tracts are census tracts with NSP scores in the top quintile. NSP census tracts are tracts that the program identifies as highly distressed. The NSP was established by Congress to assist state and local governments in supporting neighborhoods experiencing high levels of foreclosure. Funds were targeted to households with incomes less than 120 percent of the area median income. More information is available at to www.hud.gov/nsp.
} 
Denial rates (denied loans as a percentage of total applications) in New England declined slightly from 16.7 percent in 2009 to 15.9 percent in 2010, the lowest level in the past five years. However, rates and changes differ depending on the loan purpose. Home-purchase denial rates actually went up somewhat in 2010. (See Figure 8.)

However, refinance denial rates continued to decline in the region, and at 16.6 percent, they were 35 percent lower than in 2006. If we exclude Massachusetts, though, a fifth of refinance loans were denied in New England in 2010, on average. (See Figure 9.)

Figure 8

Home-Purchase and Refinance Loan Denial Rates in New England, 2006-2010

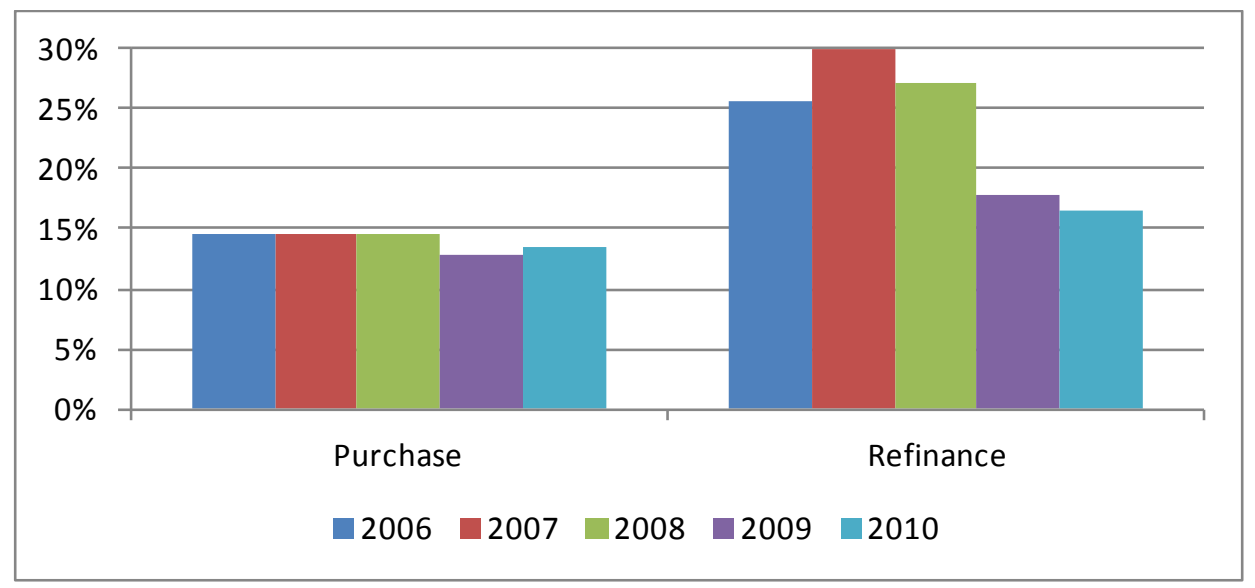

Figure 9

New England Home-Purchase and Refinance Loan Denial Rates by State: 2006, 2009, and 2010
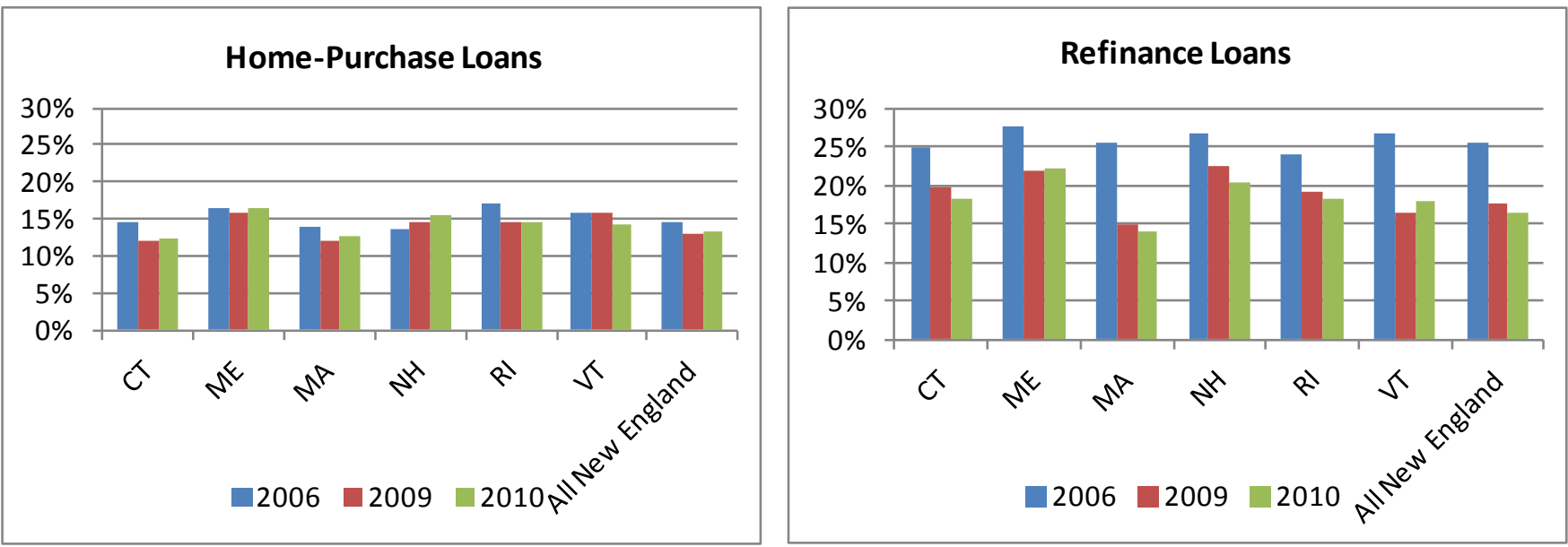
Home-purchase denial rates remained basically unchanged across race/ethnicity from 2009 to 2010 and were lower for blacks and Latinos in 2010 than in 2006. (See Figure 10.) Refinance denial rates went down marginally for all racial and ethnic groups over the same period. ${ }^{12}$ Latinos experienced the largest drop in refinance denial rates, from 29 percent in 2009 to 25 percent in 2010.

Figure 10

Denial Rates by Race/Ethnicity in New England, 2006 and 2010

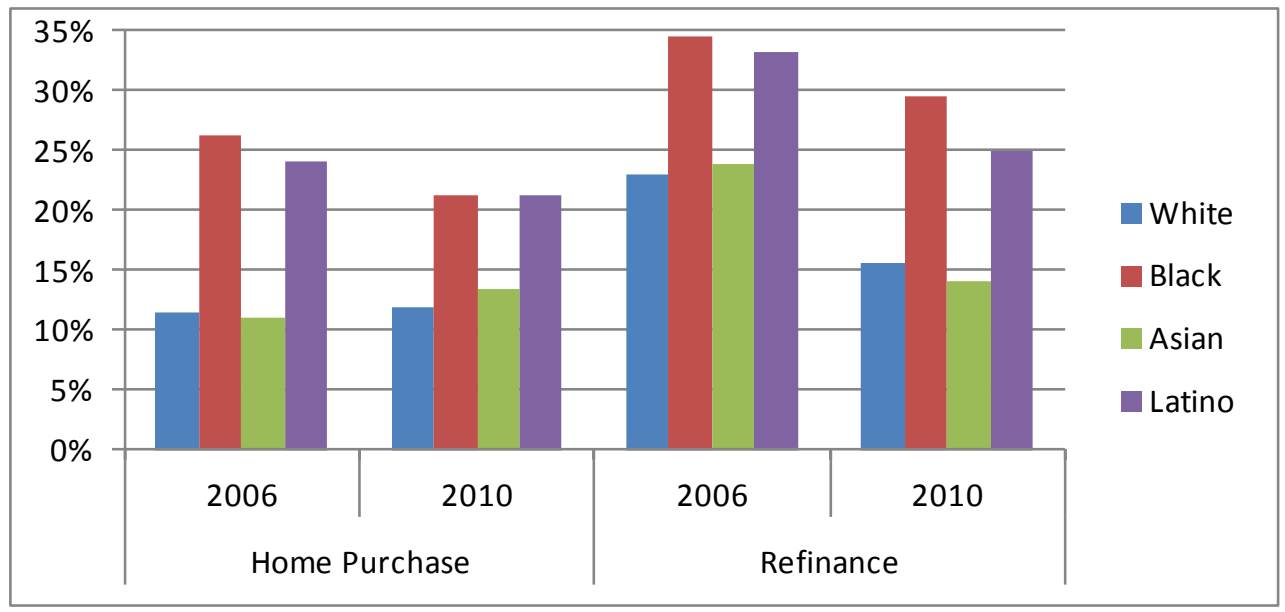

Despite the declines, disparities persist. Home-purchase denial rates among blacks and Latinos were 1.8 times higher than those for whites in 2010. Even within the same income range, blacks and Latinos experience much higher denial rates than whites and Asians. For example, black borrowers earning from $\$ 91,000$ to $\$ 120,000$ faced a denial rate that was two times higher than the denial rate for whites in that income bracket. (See Figure 11.)

\footnotetext{
${ }^{12}$ Refinance denial rates in 2009 were 17 percent for whites, 32 percent for blacks, and 15 percent for Asians.
} 
Figure 11

\section{Black and Latino Denial Disparity Ratios by Income, 2010}



As subprime lending pretty much disappeared after the housing crisis and credit conditions tightened, loans ensured by the Federal Housing Administration (FHA) became an important channel for borrowers who could not afford a 20 percent down payment. ${ }^{13}$ Although the percentage of FHA loans decreased somewhat across New England in 2010, such loans nevertheless accounted for a third of home-purchase originations in the region. (See Figure 12.) Loans from the Farm Service Agency (FSA) or Veterans Administration (VA) also played a role.

Figure 12

\section{Home-Mortgage Loan Origination in New England by Type of Loan, 2006 and 2010}

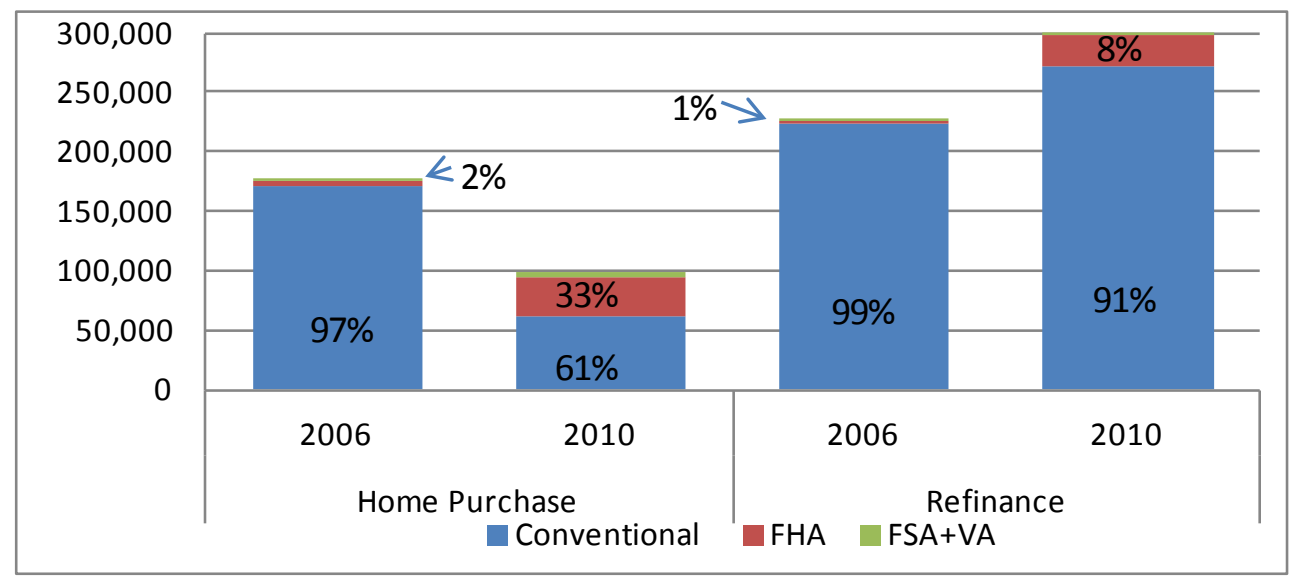

\footnotetext{
${ }^{13}$ The FHA provides mortgage insurance on loans made by FHA-approved lenders. Mortgage insurance protects lenders against losses that result from defaults on home mortgages. FHA requirements include mortgage insurance primarily for borrowers making a down payment of less than 20 percent.
} 
The share of conventional loans for home purchases in the nation went down from 91 percent in 2006 to 47 percent in 2010, and in refinance mortgages from 97 percent to 86 percent. ${ }^{14}$ In 2010, less than half of home-purchase mortgages in New Hampshire and Rhode Island were conventional loans, down markedly from close to 95 percent in 2006. (See Figure 13.) In Maine, a fifth of home-purchase loans were guaranteed by the FSA.

Figure 13

\section{New England Home-Mortgage Loan Originations by State and Type of Loan (as a Percentage of Total Originations), 2010}

Home-Purchase Loans

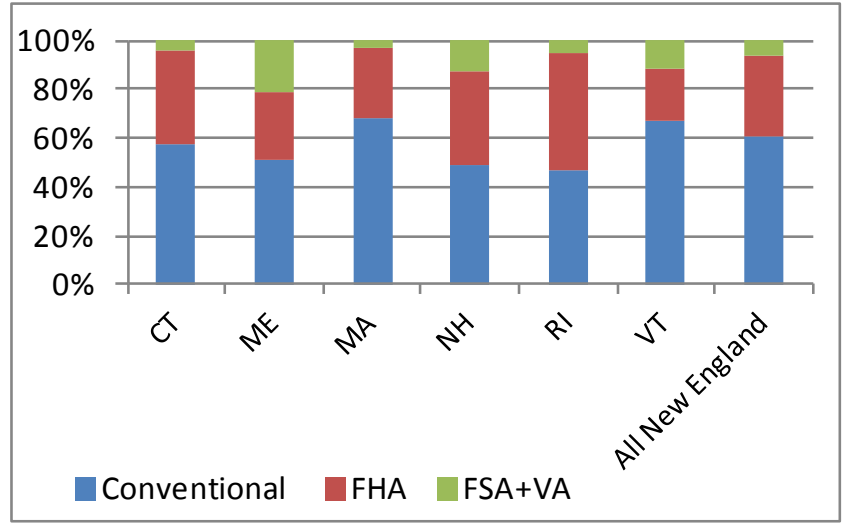

\section{Refinance Loans}

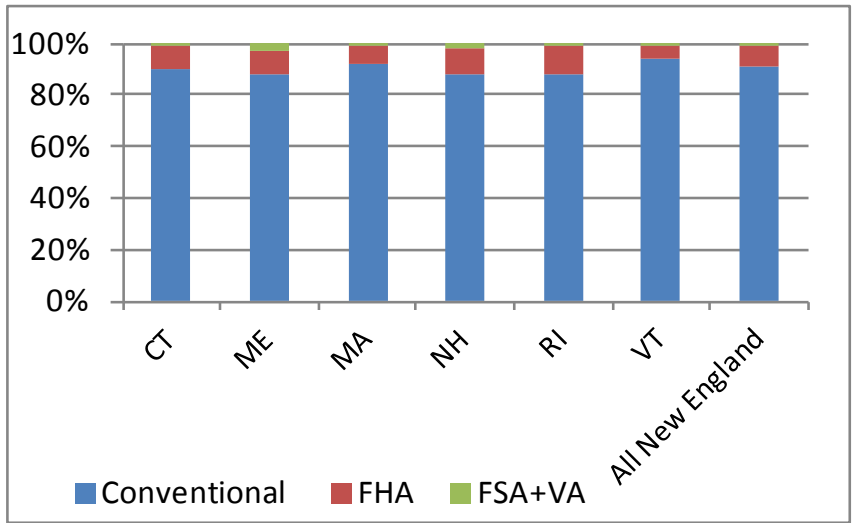

An analysis by race/ethnicity highlights the important role that government-backed loans are playing for certain minorities. For instance, two-thirds of home-purchase mortgages issued to blacks and Latinos in 2010 were insured by the FHA, whereas only one-third of loans issued to white borrowers in that year were insured by FHA. Asians were even less likely to get FHA loans than whites. (See Figure 14.) $)^{15}$

\footnotetext{
${ }^{14}$ Conventional loans are loans that are not guaranteed by government agencies.

15 In 2006, the percentage of FHA home-purchase loans was 4 percent among whites, 8 percent among blacks, 2 percent among Asians, and 7 percent among Latino borrowers.
} 
Figure 14

FHA Home-Purchase and Refinance Loans by Race/Ethnicity (as a Percentage of All Loans), 2010

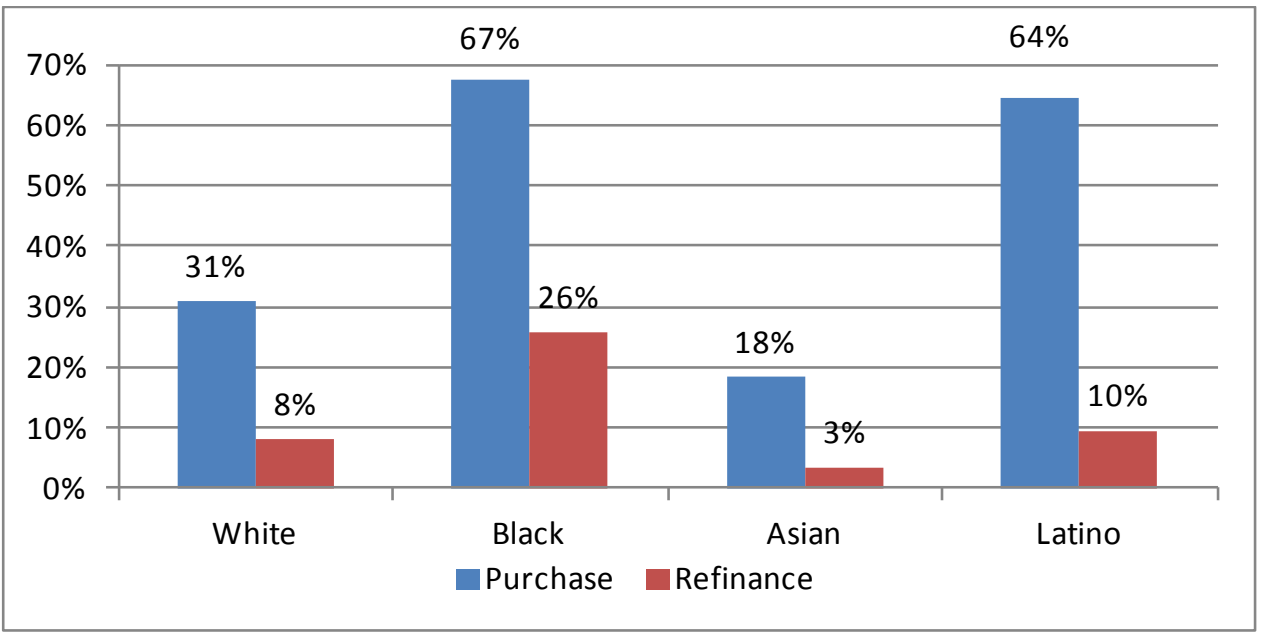

Similarly, LMI borrowers and borrowers living in LMI census tracts depended heavily on government-backed loans to finance home purchases. In New England, less than half of the 55,800 LMI borrowers received conventional loans in 2010. In the region, Rhode Island relied the most on nonconventional loans, as only a fifth of LMI census tracts and a third of LMI borrowers' loan originations in that state were conventional loans. (See Figure 15.)

Figure 15

New England Conventional Mortgage Originations by State and Borrower's Income (as a Percentage of Total Originations), 2010

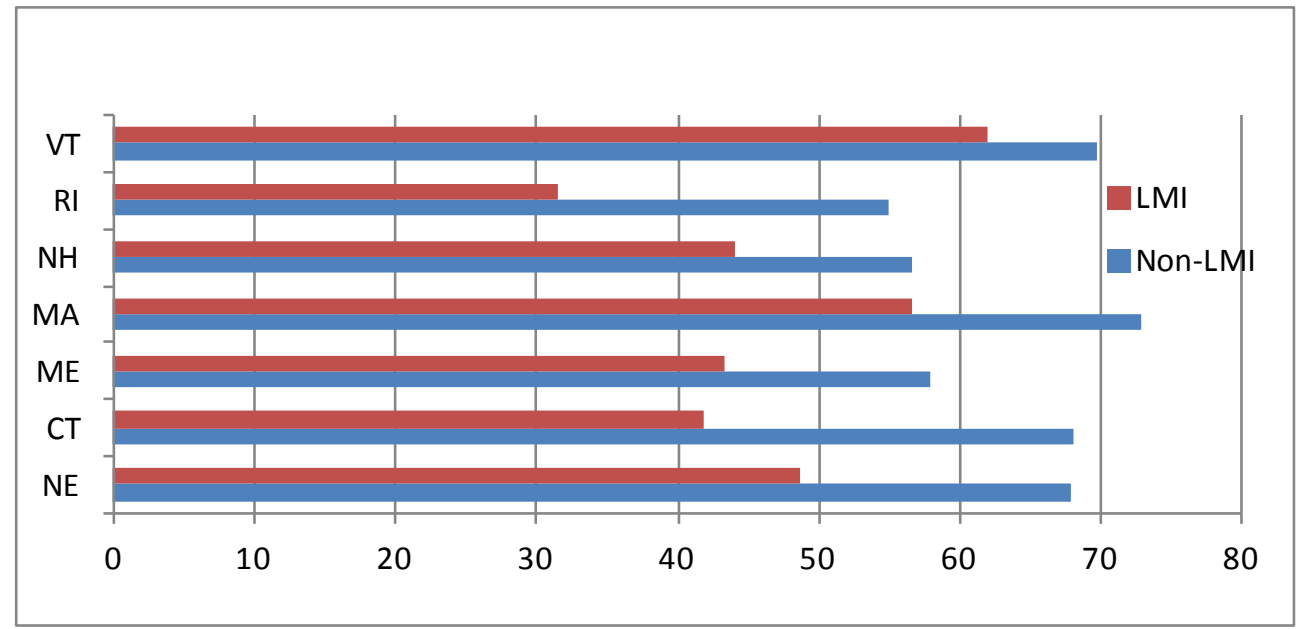


Although the 2010 HMDA data for loans with a high annual percentage rate (APR) are not comparable to the data for previous years, ${ }^{16}$ it is apparent that subprime loans played an insignificant role in the housing market, accounting for only 1 percent of refinance mortgages issued in 2010, compared with more than a quarter of refinance mortgage originations in 2006. (See Figure 16.)

Figure 16

New England Home-Purchase and Refinance High-APR Loans (as a Percentage of Total Loans), 2006-2010

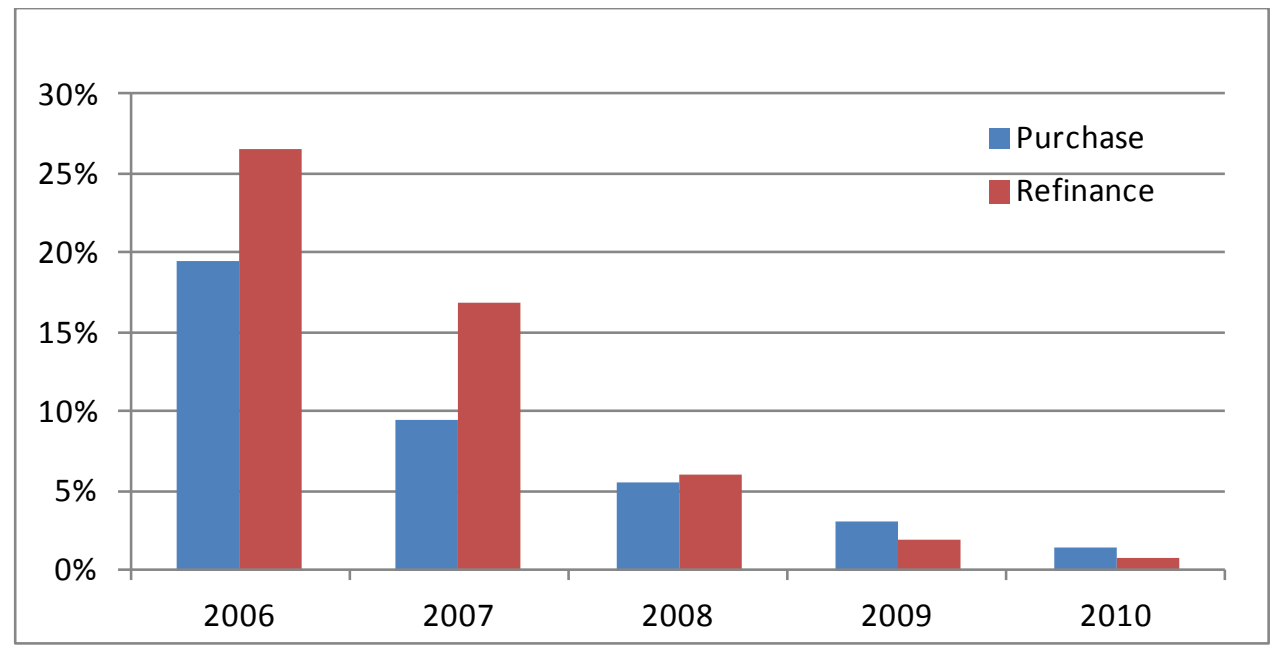

In 2006, high-APR loans accounted for more than 40 percent of mortgages granted to black and Latino borrowers, a significantly higher share than among white borrowers (19 percent) and Asian borrowers (14 percent). In 2010, only one percent of Latino and white borrowers got high-priced loans. A higher percentage of black borrowers ( 2 percent) received high-APR loans-still an insignificant amount compared to figures seen prior to the collapse in the housing bubble. (See Figure 17.)

\footnotetext{
${ }^{16}$ The data are not comparable because the thr eshold for registering a loan as a high-APR loan changed in 2009. For loans issued before October 2009, lenders had to register APRs for first liens if the spread between the APR on the loan and the yield on a Treasury security of comparable maturity was above 3 percentage points. For loans issued after October 2009, the requirement to register was triggered if the spread between the APR on the loan and the estimated APR on the lowest-risk prime loan was above 1.5 percentage points.
} 
Figure 17

New England High-APR Loans by Race/Ethnicity (as a Percentage of Total Loans), 2006-2010

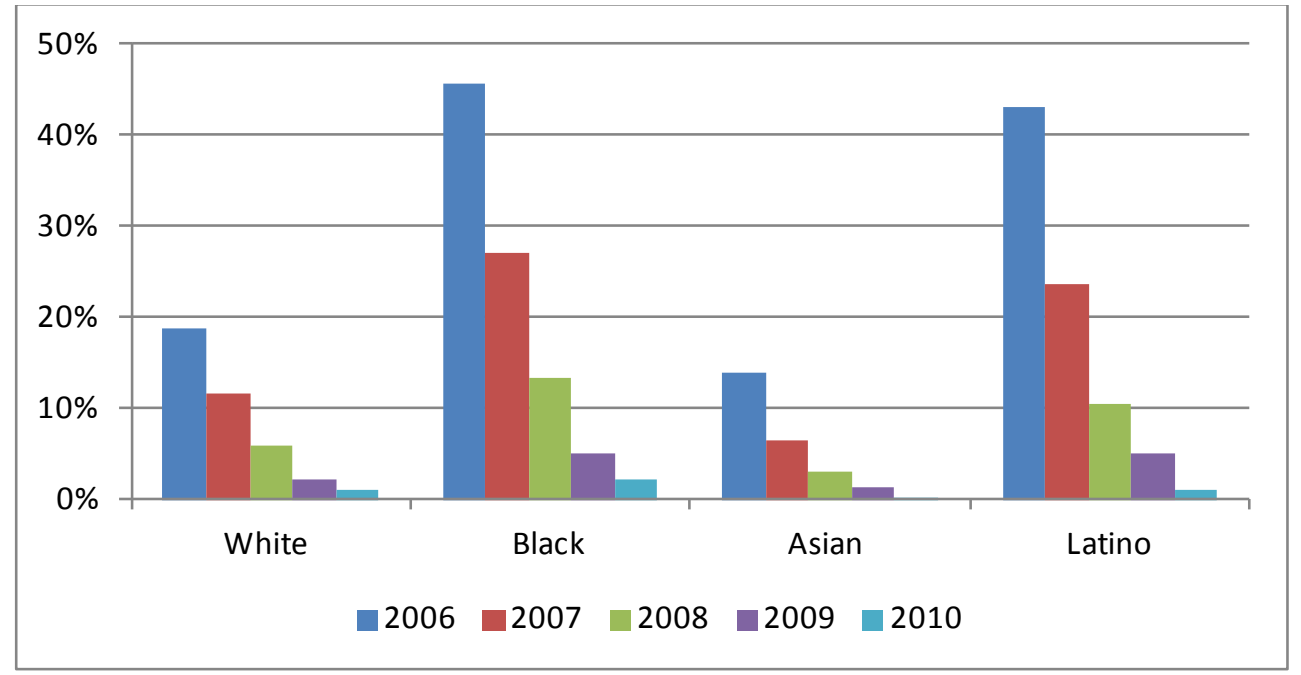

Although data available under HMDA does not provide enough information to identify the causes of disparities in lending, it does help discover interesting trends in mortgage activity. 